\title{
AKIBAT HUKUM REGULASI TENTANG THRESHOLD DALAM PEMILIHAN UMUM LEGISLATIF DAN PEMILIHAN PRESIDEN
}

Kajian Putusan Mahkamah Konstitusi

Nomor 52/PUU-X/2012 dan Nomor 14/PUU-XI/2013

\section{LEGAL IMPACT OF THE THRESHOLD REGULATION IN LEGISLATIVE AND PRESIDENTIAL ELECTION}

\author{
An Analysis of Constitutional Court Decision \\ Number 52/PUU-X/2012 and Number 14/PUU-XI/2013 \\ Sholahuddin Al-Fatih \\ Fakultas Hukum Universitas Muhammadiyah Malang \\ J1. Raya Tlogomas No. 246 Malang 65144 \\ Email: sholahuddin.alfath@gmail.com
}

Naskah diterima: 12 Oktober 2017; revisi: 11 April 2019; disetujui: 2 Mei 2019

http://dx.doi.org/10.29123/jy.v12i1.258

\section{ABSTRAK}

Indonesia telah menyelenggarakan 11 kali pemilihan umum (pemilu) sejak tahun 1955. Hingga saat ini, rezim hukum pemilu telah melahirkan banyak regulasi dan ketentuan baru, seperti aturan tentang threshold atau ambang batas. Putusan Mahkamah Konstitusi Nomor 52/PUU-X/2012 menyatakan bahwa Pasal 208 UndangUndang Nomor 8 Tahun 2012 tentang Pemilu Legislatif terkait dengan ambang batas parlemen (parliamentary threshold) sebesar 3,5\% tidak berlaku secara nasional. Melengkapi putusan tersebut, Mahkamah Konstitusi melalui Putusan Nomor 14/PUU-XI/2013 menyebutkan bahwa pemilu tahun 2019 berlaku secara serentak, yang secara yuridis berdampak pada pola penerapan threshold. Rumusan masalah yang akan diurai dalam penelitian ini adalah bagaimana akibat hukum regulasi tentang threshold dalam pemilihan umum legislatif dan pemilihan presiden pasca Putusan Mahkamah Konstitusi Nomor 52/PUU-X/2012 dan Nomor 14/PUU-XI/2013. Metode yang digunakan dalam penelitian ini adalah metode penelitian yuridis normatif. Hasil penelitian menunjukkan bahwa dalam konteks negara demokrasi,
\end{abstract}

ambang batas atau threshold diterapkan sebagai batas untuk menyaring kandidat anggota legislatif ataupun presiden yang bersifat open legal policy dan diserahkan kepada pembuat undang-undang.

Kata kunci: pemilihan umum legislatif, pemilihan presiden, ambang batas.

\section{ABSTRACT}

Indonesia has held 11 general elections since 1955. Up to now, the regime of general electoral law has given birth to many new regulations and provisions, such as regulations on threshold. The Constitutional Court Decision Number 52/PUU-X/2012 states that Article 208 of Law Number 8 of 2012 concerning the Legislative Election with a parliamentary threshold of $3.5 \%$ does not apply on a national scale. Complementing the ruling, the Constitutional Court through Decision Number 14/ PUU-XI/2013 states the 2019 general election applies simultaneously that it may bring juridical effect on the pattern of threshold application. The formulation of the problem to be explained in this analysis is how the legal 
impact of the regulation on threshold in legislative and presidential elections after the issuance of Constitutional Court Decision Number 52/PUU-X/2012 and Number 14/PUU-XI/2013. This analysis uses a normative juridical research method. The results of the study show that in the context of a democratic country, the threshold is applied as a limit to filter out presidential candidates or legislative members, which is open legal policy and submitted to lawmakers.

Keywords: legislative election, presidential election, threshold.

\section{PENDAHULUAN}

\section{A. Latar Belakang}

Indonesia telah menyelenggarakan pemilu sebanyak 11 kali, mulai dari pemilu pertama di tahun 1955, hingga pemilu terakhir di tahun 2014. Pemilu tersebut secara berturut-turut diselenggarakan pada tahun 1955, 1971, 1977, 1982, 1987, 1992, 1997, 1999, 2004, 2099, dan 2014. Pemilu pertama di tahun 1955 disebut sebagai pemilu terbaik sepanjang sejarah penyelenggaraan pemilu di Indonesia karena mampu memberikan rasa aman dan memenuhi unsur demokratis dengan jumlah peserta pemilu sebanyak 27 partai politik dan satu peserta perseorangan (Erfandi, 2014: 148). Bahkan, pemilu tahun 1955 hampir tidak ditemukan konflik dan memenuhi unsur demokratis karena hampir semua elemen masyarakat terlibat, baik partai maupun perseorangan sebagai peserta pemilu (Asshiddiqie, 2006: 169). Meskipun dalam pemilu 1955 tersebut terdapat anggota parlemen maupun menteri yang terlibat dalam kandidasi pemilihan, namun mereka tak menggunakan fasilitas atau jabatan yang melekat pada dirinya sebagai upaya untuk meraih suara masyarakat (Soedarsono, 2006: 9).

Pasca pemilu tahun 1955, era demokratisasi pemilu banyak dikaitkan dengan pemilu tahun 2004, karena dalam pemilu tersebut untuk pertama kalinya presiden dan wakil presiden dipilih secara langsung oleh rakyat. Pemilu tahun
2004 juga identik dengan diberlakukannya aturan baru dalam rezim hukum pemilu, yaitu dengan diberlakukannya mekanisme ambang batas atau biasa dikenal sebagai threshold. Threshold atau lebih tepatnya electoral threshold saat itu merujuk pada ketentuan dalam Pasal 39 ayat (3) Undang-Undang Nomor 3 Tahun 1999 tentang Pemilihan Umum.

Saat pertama kali diperkenalkan, electoral threshold didefinisikan sebagai ambang batas minimal bagi partai agar bisa mengikuti pemilu pada periode berikutnya. Sebelum pemilu tahun 2004 diselenggarakan, ketentuan mengenai threshold diatur dalam Pasal 143 ayat (1) Undang-Undang Nomor 12 Tahun 2003 tentang Pemilihan Umum Anggota Dewan Perwakilan Rakyat, Dewan Perwakilan Daerah, dan Dewan Perwakilan Rakyat Daerah. Tidak hanya berlaku untuk rezim pemilu legislatif, tetapi juga untuk menjaring calon presiden dan wakilnya, di mana pemerintah juga menerapkan apa yang disebut sebagai presidential threshold yang diatur dalam Pasal 5 ayat (5) Undang-Undang Nomor 23 Tahun 2003. Sejak saat itu, hampir di setiap periode pemilu, diberlakukan aturan tentang ambang batas (threshold) dan selalu direvisi dengan perubahan istilah ataupun besaran angkanya.

Threshold yang dipakai dalam rezim pemilu tahun 2004 juga diadopsi dalam pemilu tahun 2009. Dalam panitia khusus (pansus) RUU Pemilu, pemerintah dan lembaga legislatif 
sepakat merubah istilah electoral threshold yang digunakan dalam pemilu sebelumnya menjadi parliamentary threshold. Regulasi threshold untuk pemilu tahun 2009 disebutkan di dalam Undang-Undang Nomor 10 Tahun 2008 dan Undang-Undang Nomor 42 Tahun 2008. Penyelenggaraan pemilu tahun 2014, regulasi mengenai ketentuan threshold diatur dalam Undang-Undang Nomor 8 Tahun 2012 tentang Pemilu Legislatif, sementara untuk regulasi mengenai presidential threshold tidak dirubah dan tetap mengacu pada Undang-Undang Nomor 42 Tahun 2008 tentang Pemilihan Presiden.

Sepanjang pemberlakuan threshold tersebut, masyarakat terutama partai politik (parpol) telah beberapa kali melakukan judicial review ke Mahkamah Konstitusi untuk menguji keabsahan pemberlakuan threshold di dalam pemilu. Alasan pengujian tersebut lebih banyak dilandasi pada perlindungan hak asasi manusia, terutama hak sipil dan politik warga negara yang secara sistemik dianggap dapat dikebiri dengan diberlakukannya mekanisme threshold, karena akan banyak suara pemilih terbuang melalui mekanisme tersebut. Meskipun demikian, Mahkamah Konstitusi melalui Putusan Nomor 3/PUU-VII/2009 justru semakin memperkuat eksistensi threshold dengan amar putusan yang menyebutkan bahwa penerapan threshold merupakan hal yang wajar untuk penyederhanaan partai.

Mahkamah Konstitusi juga berpendapat bahwa sekalipun tidak diatur secara tertulis dalam undang-undang, pada dasarnya juga akan tetap berlaku threshold alami. Threshold dianggap tidak melanggar nilai-nilai hak asasi manusia karena threshold berlaku bagi seluruh peserta pemilu. Selain mempertanyakan soal keabsahan threshold, masyarakat dan parpol juga banyak bertanya tentang besaran angka yang menjadi batas threshold serta lingkup keberlakuannya. Sebagaimana disebutkan dalam Putusan Nomor 52/PUU-X/2012, Mahkamah Konstitusi membatalkan Pasal 208 UndangUndang Nomor 8 Tahun 2012 karena menilai bahwa penerapan parliamentary threshold secara nasional merampas hak suara pemilih partai kecil di daerah. Putusan Mahkamah Konstitusi tersebut tidak bulat karena terdapat dissenting opinion dari Hakim Konstitusi M. Akil Mochtar. Akil Mochtar berpendapat bahwa penerapan threshold tidak sesuai dengan semangat demokrasi yang mengusung prinsip keterwakilan (representativeness).

Pendapat berbeda dari Akil Mochtar tersebut juga telah disampaikannya dalam Putusan Mahkamah Konstitusi Nomor 3/PUUVII/2009. Selain berkaitan dengan parliamentary threshold dalam pemilu legislatif, terdapat juga permasalahan dalam regulasi terkait presidential threshold dalam pemilihan presiden, terutama setelah keluarnya Putusan Mahkamah Konstitusi Nomor 14/PUU-XI/2013. Gugatan yang dilakukan oleh Efendi Ghazali tersebut mempersoalkan efektivitas penyelenggaraan pemilu. Pemohon mendalilkan bahwa pemilu yang diselenggarakan secara terpisah sangat tidak efektif, berbiaya mahal, rawan menimbulkan konflik yang berkepanjangan (Asprian, 2014). Putusan tersebut memberikan implikasi yuridis bahwa pemilu tahun 2019 diselenggarakan secara serentak. Threshold yang dicetuskan oleh para pembuat undang-undang, ditafsirkan secara berbeda oleh para Hakim Konstitusi. Problematika regulasi mengenai threshold dalam putusan Mahkamah Konstitusi tersebut menarik untuk dikaji lebih dalam, terutama terkait dengan disahkannya undang-undang pemilu, yaitu Undang-Undang Nomor 7 Tahun 2017. 


\section{B. Rumusan Masalah}

Berdasarkan uraian di atas, maka dapat dirumuskan permasalahan, yaitu: Bagaimana akibat hukum regulasi tentang threshold dalam pemilu legislatif dan pemilihan presiden pasca Putusan Mahkamah Konstitusi Nomor 52/ PUU-X/2012 dan Nomor 14/PUU-XI/2013?

\section{Tujuan dan Kegunaan}

Merujuk pada rumusan masalah, maka tulisan ini bertujuan untuk menelusuri akibat hukum regulasi tentang threshold dalam negara demokrasi Indonesia pasca Putusan Mahkamah Konstitusi Nomor 52/PUU-X/2012 dan Nomor 14/PUU-XI/2013. Lebih lanjut, tulisan ini diharapkan memiliki kegunaan sebagai berikut:

1. Secara teoritis hasil penelitian ini adalah untuk memberikan pengembangan ilmu hukum, khususnya yang terkait dengan hukum pemilu berkaitan dengan penerapan threshold dalam penyelenggaraan pemilu di Indonesia.

2. Secara praktis, hasil penelitian ini juga akan berguna bagi kalangan praktisi, baik itu partai politik, Komisi Pemilihan Umum, pemerintah, akademisi maupun pemerhati hukum pemilu.

\section{Tinjauan Pustaka}

\section{Pemilihan Umum Legislatif dan Presiden}

Sejak awal proklamasi kemerdekaan, Indonesia telah menasbihkan dirinya sebagai negara demokrasi atau lebih tepatnya demokrasi Pancasila. Keterlibatan rakyat dalam negara demokrasi nampak dalam tiga hal utama, yaitu melalui partisipasi, representasi, dan pengawasan. Salah satu sarana utama bagi rakyat untuk menjalankan kedaulatannya adalah melalui pemilu (Appadorai, 1974: 523). Kata pemilu merupakan akronim dari dua kata, yaitu pemilihan dan umum. Sedangkan kata pemilihan berasal dari kata dasar pilih. Dalam Kamus Besar Bahasa Indonesia, kata pilih mengandung arti, "dengan teliti memilih, tidak dengan sembarangan saja, mengambil mana-mana yang disukai, mencari atau mengasingkan mana-mana yang baik, menunjuk orang, calon." Kata umum berarti, "mengenai seluruhnya atau semuanya, secara menyeluruh, tidak menyangkut yang khusus (tertentu) saja” (Depdiknas, 2012).

Berdasarkan definisi tersebut dapat disimpulkan bahwa definisi pemilu adalah memilih dengan cermat, teliti, saksama sesuai hati nurani seorang wakil yang dapat membawa amanah dan dapat menjalankan kehendak pemilih (Sodikin, 2014: 2). Melalui mekanisme pemilu inilah, rakyat selaku pemegang kekuasaan tertinggi bisa menggunakan hak-haknya untuk memilih para wakilnya. Karena dengan memilih dan menggunakan haknya tersebut, rakyat mendapatkan legitimasi untuk kemudian meminta pertanggungjawaban kepada para wakil rakyat terpilih, jika di kemudian hari mereka tak mampu merepresentasikan kebutuhan rakyat. Di sinilah mekanisme pengawasan dijalankan sepenuhnya oleh rakyat. Di Indonesia sendiri, terdapat beberapa pemilu yang dilaksanakan untuk memilih para wakil rakyat, di antaranya adalah:

1. Pemilu Legislatif (pileg), untuk memilih anggota Dewan Perwakilan Rakyat, Dewan Perwakilan Daerah, dan Dewan Perwakilan Rakyat Daerah;

2. Pemilu Presiden (pilpres), untuk memilih presiden dan wakil presiden; dan 
3. Pemilu Kepala Daerah (pemilukada), untuk memilih kepala daerah, baik gubernur, bupati ataupun walikota.

Landasan yuridis perlunya diselenggarakan pemilu di Indonesia telah diatur secara konstitusional dalam UUD NRI 1945, di antaranya (Al-Fatih, 2015: 34):

1. Pasal 1 ayat (2) UUD NRI 1945 yang berbunyi: "Kedaulatan berada di tangan rakyat dan dilaksanakan menurut Undang-Undang Dasar." Pasal ini menunjukkan bahwa untuk melaksanakan dan mengaplikasikan kedaulatan rakyat, perlu diimplementasikan melalui pemilu.

2. Pasal 2 ayat (1) UUD NRI 1945 menyatakan bahwa: "Majelis Permusyawaratan Rakyat terdiri atas anggota Dewan Perwakilan Rakyat dan anggota Dewan Perwakilan Daerah yang dipilih melalui pemilihan umum dan diatur lebih lanjut dengan undang-undang." Pasal ini menunjukkan bahwa anggota Majelis Permusyawaratan Rakyat yang terdiri dari anggota Dewan Perwakilan Rakyat dan Dewan Perwakilan Daerah dipilih melalui pemilu. Penjelasan yang sama juga terdapat dalam Pasal 19 ayat (1) dan Pasal 22C UUD NRI 1945.

3. Pasal 6A ayat (1) UUD NRI 1945 menyebutkan: "Presiden dan Wakil Presiden dipilih dalam satu pasangan secara langsung oleh rakyat." Frasa kalimat dipilih langsung oleh rakyat merupakan indikasi dari pemilihan langsung melalui pemilu. Lebih lanjut terkait amanat pemilu presiden dan wakil presiden, dijelaskan dalam Pasal 6A ayat (2), (3), (4), dan (5) UUD NRI 1945.

4. Pasal 18 ayat (4) UUD NRI 1945 menyatakan: "Gubernur, Bupati, dan Walikota masing-masing sebagai kepala pemerintahan daerah provinsi, kabupaten, dan kota dipilih secara demokratis." Frasa kalimat dipilih secara demokratis juga merupakan indikator bahwa pemilukada dilaksanakan melalui mekanisme pemilu.

5. Pasal 22E terkait pemilu, yang dijabarkan dalam enam ayat, yaitu Pasal 22E ayat (1), (2), (3), (4), (5), dan (6).

Indonesia sebagai negara hukum dengan kedaulatan tertinggi berada di tangan rakyat, memiliki beberapa implikasi yuridis yang erat kaitannya dengan pemilu. Konsep negara hukum yang digagas oleh Plato dan Aristoteles, menghendaki terciptanya kehidupan yang harmonis dalam bingkai negara hukum (Hakim, 2011: 2). Salah satu parameter mewujudkan kehidupan yang harmonis tersebut, bisa dilihat dari penyelenggaraan pemilunya. Hal ini dikarenakan di dalam negara hukum, pemilu diperlukan untuk menjamin bahwa hukum dibuat secara demokratis, yaitu oleh lembaga yang dipilih oleh rakyat melalui cara-cara yang demokratis, yaitu pemilu (Asshiddiqie, 2010: 362). Pemilihan para organ penyelenggara pemerintah secara demokratis tersebut untuk menjamin terpenuhinya unsur representasif. Dalam penyelenggaraan pemilu, minimal ada empat hal yang harus dipenuhi, yaitu: konstituen atau pemilih, kandidat atau calon terpilih, cara memilih, dan jabatan atau kedudukan yang karenanya diadakan pemilu (Ash-Shallabi, 2016: 79).

Melalui pemilihan terhadap wakil-wakil rakyat tersebut, rakyat sebenarnya sedang dilibatkan dalam penentuan pembentuk undangundang. Karena pada dasarnya pemilu adalah untuk memilih wakil rakyat yang nantinya menjalankan fungsi legislasi, yaitu sebagai pembuat produk hukum. Tidak hanya itu saja, dalam kaitannya dengan pemenuhan prinsip- 
prinsip hak asasi manusia, pemilu berupaya mengakomodir kebutuhan hak asasi manusia, dalam hal hak untuk memilih dan dipilih serta persamaan hak di hadapan hukum bagi seluruh warga negara (Mahfud MD, 1999: 221-222). Bahkan, hak memilih (right to be vote) dan hak untuk dipilih (right to be candidate) tidak hanya diatur secara konstitusional dalam konstitusi saja, tetapi juga telah diatur secara universal dalam kovenan-kovenan internasional (Isra et al., 2014: 432). Dengan demikian, pemilu tidak hanya merupakan elemen penting dalam negara demokratis, namun juga sebagai upaya pemenuhan dan jaminan terhadap hak asasi manusia.

Sebagai bentuk pemenuhan terhadap unsur-unsur demokratis, maka pemilu harus dilaksanakan secara berkala (Asshiddiqie, 2009: 378). Hal ini penting karena ada beberapa faktor yang memengaruhinya, yaitu: Pertama, pendapat atau aspirasi masyarakat mengenai berbagai aspek kehidupan berbangsa dan bernegara cenderung bersifat dinamis. Oleh karena itu pemilu perlu dibuat berkala untuk mengakomodasi hal tersebut. Kedua, selain karena faktor perubahan pendapat masyarakat, faktor eksternal dalam kehidupan masyarakat juga menjadi pertimbangan. Perubahan bisa datang dari dinamisasi internasional dan faktorfaktor luar lainnya. Perubahan inilah yang menyebabkan iklim politik bersifat dinamis. Ketiga, perubahan karakter pemilih, seperti munculnya pemilih pemula yang cukup banyak, kecerdasan berpolitik yang meningkat, dan sebagainya. Keempat, pemilu perlu dilakukan secara berkala untuk memberikan regenerasi di puncak pemegang kekuasaan. Pergantian tongkat estafet kepemimpinan diharapkan akan merubah pula kondisi negara. Di Indonesia, pemilu dilakukan secara berkala setiap lima tahun sekali (Asshiddiqie, 2009: 378).

Pemilu dapat dilaksanakan dengan dua macam sistem yaitu sistem perwakilan berimbang (proportional representative) dan sistem distrik (single-member-constituency). Sistem distrik disebut juga sebagai the winner's take all, karena dalam sistem ini wilayah negara dibagi dalam distrik-distrik pemilihan atau daerah-daerah pemilihan yang jumlahnya sama dengan dengan jumlah anggota lembaga perwakilan rakyat yang diperlukan untuk dipilih. Kelebihan dari sistem distrik adalah bahwa setiap calon dari suatu distrik, biasanya berasal dari daerah itu sendiri atau meskipun datang dari daerah lain, tetapi orang tersebut dikenal oleh masyarakat di daerah yang bersangkutan. Dengan demikian, hubungan antara para pemilih dan calon perwakilan memiliki hubungan yang erat dan saling mengenal dengan baik (Corry, 1960: 226).

Dalam sistem perwakilan berimbang (proporsional), persentase kursi di lembaga perwakilan rakyat dibagikan kepada tiap-tiap partai politik sesuai dengan persentase yang diperoleh oleh tiap partai politik tersebut. Oleh sebab itu, pembagian kursi di badan perwakilan rakyat tersebut tergantung kepada berapa jumlah suara yang didapat oleh partai politik yang ikut pemilihan umum. Apabila memakai sistem proporsional ini, maka dalam bentuk aslinya tidak perlu lagi membagikan korps pemilih atas jumlah daerah pemilihan. Korps pemilih boleh dibagi atas sejumlah daerah pemilihan dengan ketentuan bahwa setiap daerah pemilihan disediakan beberapa kursi sesuai dengan jumlah penduduknya (Asshiddiqie, 2006: 183-184). Sistem proporsional ini juga dikenal sebagai sistem yang agak rumit dalam penghitungannya. 
Indonesia sendiri sejak rezim pemilu legislatif tahun 2004 menganut sistem proporsional daftar terbuka untuk pemilihan anggota Dewan Perwakilan Rakyat dan Dewan Perwakilan Rakyat Daerah, serta sistem distrik berwakil banyak untuk pemilihan anggota Dewan Perwakilan Daerah. Sistem ini dalam perjalanannya tetap diadopsi dalam rezim pemilu tahun 2009 dan 2014. Organ penyelenggara pemilu di Indonesia terdiri dari Komisi Pemilihan Umum, Badan Pengawas Pemilu, dan Dewan Kehormatan Penyelenggara Pemilu.

\section{Ambang Batas (Threshold)}

Salah satu instrumen baru dalam hukum pemilu yang lahir di era reformasi adalah mengenai ambang batas atau lebih dikenal dengan threshold. Threshold dalam kamus Oxford Advanced Learner's Dictionary berarti batasan tertentu untuk memulai sesuatu (the level at which something starts to happen) (Hornby, 2003: 1408). Lijphart mendefinisikan threshold sebagai a minimum number of seats won in the lower-tier district and/or a minimum percentage of a total national vote (Lijphart, 2012: 12). Sedangkan menurut Kamus Besar Bahasa Indonesia, ambang batas berarti tingkatan batas yang masih dapat diterima atau ditoleransi (Depdiknas, 2012: 48).

Ambang batas atau threshold merupakan salah satu instrumen teknis pemilu yang ditemui dalam negara-negara yang menerapkan sistem pemilu proporsional, termasuk di Indonesia. Menurut Mellaz, threshold, electoral threshold, ataupun parliamentary threshold pada dasarnya sama, yakni ambang batas (syarat) yang harus dilampaui oleh partai politik, untuk dapat mengirimkan wakilnya ke lembaga perwakilan
(Mellaz, 2012 dan Gumay, 2011).

Threshold, electoral threshold, presidential threshold ataupun parliamentary threshold biasanya dinyatakan dengan persentase perolehan suara sah atau di beberapa negara bisa dinyatakan dalam bentuk perolehan minimal kursi (minimum seats), di mana istilah tersebut lazim digunakan dalam konteks pemilihan umum. Kebijakan terkait threshold juga dapat digunakan sebagai parameter untuk menentukan kondisi demokrasi di suatu negara.

Terdapat dua karakter negara demokrasi, yaitu negara demokrasi transisi dan negara demokrasi mapan. Biasanya, negara demokrasi transisi, terutama yang sedang bergerak dari situasi dan gejolak konflik yang mendalam, lebih memerlukan keterikatan di antara semua pihak. Dengan demikian, dibutuhkan threshold yang rendah bagi partai peserta pemilu agar bisa menyuarakan aspirasinya. Sementara untuk negara demokrasi mapan, biasanya lebih memilih threshold yang lebih tinggi (Reilly \& Reynolds, 2001: 16).

Pilihan threshold yang rendah bagi negara demokrasi transisi lebih menitikberatkan pada upaya pemberian hak kepada semua lapisan masyarakat untuk bersama-sama membangun pemerintahan. Sedangkan pada negara demokrasi mapan, pilihan threshold tinggi bertujuan untuk menciptakan efektivitas kinerja pemerintahan dengan batasan yang telah ditetapkan tersebut.

Kriteria semacam itu lazim dipakai untuk mengurangi jumlah kepentingan yang kecil atau golongan dalam lembaga legislatif dan untuk mempercerah prospek terbentuknya pemerintah yang berjalan dengan baik (Goodwin-Gill, 1994: 12). 
Terdapat perbedaan penerapan threshold untuk negara demokrasi mapan dengan negara demokrasi transisi. Berdasarkan pengalaman penelitian di negara-negara Eropa Tengah dan Timur, Moraski \& Loewenberg (1999:168) mengungkapkan bahwa diterapkannya threshold dalam sebuah sistem pemilu di suatu negara pada dasarnya hanya akan menguntungkan perolehan suara partai mayoritas.

Sebagaimana diketahui, negara-negara di kawasan Eropa Tengah dan Timur mayoritas masuk ke dalam fase negara demokrasi transisi pasca berkembangnya era paham komunis sebagai eks-bagian dari negara Yugoslavia dan Uni Soviet. Di kawasan Eropa Tengah dan Timur tersebut, pemberlakuan threshold secara teknis berpengaruh terhadap peningkatan jumlah perolehan kursi partai politik dengan suara mayoritas dari satu periode pemilu ke periode berikutnya. Akan tetapi dari sudut pandang positif, dengan adanya kebijakan threshold maka daya saing antar partai politik untuk mendapatkan dukungan dari masyarakat semakin meningkat. Tingkat persaingan diharapkan meningkat sekaligus menekan angka fragmentasi di antara partai di parlemen.

Penerapan threshold di Eropa Tengah dan Timur tersebut mengindikasikan bahwa pada dasarnya terdapat keragaman dalam mengimplementasikan kebijakan threshold di masing-masing negara. Ketentuan tentang threshold di masing-masing negara umumnya dipengaruhi oleh keberadaan kultural dan sejarah dari berdirinya negara tersebut. Beberapa referensi mengenai pemberlakuan threshold di beberapa negara menunjukkan variabel yang berbeda. Negara-negara di dunia yang menerapkan threshold, tidak memiliki batasan yang mutlak (Firdaus, 2011: 95).
Konsep threshold awalnya digunakan untuk melihat tingkat kompetisi partai dalam memperebutkan kursi di daerah pemilihan dalam sistem pemilu proporsional. Konsep itu menghubungkan besaran daerah pemilihan (district magnitude) dengan formula perolehan kursi partai dengan metode kuota.

Terlepas dari rumitnya perhitungan mengenai threshold, penerapan kebijakan tersebut tentunya mengandung tujuan tertentu. Biasanya tujuan penerapan threshold bergantung pada kebutuhan masing-masing negara. Sebagai contoh, pemberlakuan parliamentary threshold sebesar 5\% di Jerman. Ambang batas tersebut bertujuan membatasi terpilihnya kelompok ekstremis, serta menghentikan partai-partai kecil sehingga tidak mendapatkan perwakilan (Junaidi et al., 2013: 117). Di Polandia, threshold ditetapkan sebesar 5\% untuk setiap partai politik dan $8 \%$ untuk koalisi partai politik. Salah satu alasan mengapa ambang batas di Polandia sangat tinggi adalah sebagai upaya untuk menyingkirkan partai-partai yang cenderung pro-komunis di Polandia pasca runtuhnya Uni Soviet (Jurdi, 2011).

Sementara di Moldova, threshold diberlakukan untuk mengurangi fragmentasi dalam sistem kepartaian dengan cara membatasi jumlah partai (terutama partai kecil) untuk dapat masuk ke parlemen (Senyuva, 2010: 1). Alasan-alasan inilah yang kemudian menjadikan threshold tetap eksis dan diberlakukan di negaranegara tersebut. Sementara bagi Indonesia sendiri, sebagai salah satu norma hukum yang baru lahir di era reformasi, threshold memang sengaja difungsikan sebagai konsentrasi pembangunan hukum dalam rangka visualisasi demokrasi yang lebih baik (Raditya, 2013: 2). 


\section{METODE}

Metode yang digunakan dalam tulisan ini adalah metode penelitian hukum yuridis normatif. Penelitian hukum normatif yaitu penelitian dengan studi kepustakaan melalui pendekatan yang dilakukan berdasarkan bahan hukum utama dengan cara menelaah teori-teori, konsep-konsep asas-asas hukum, norma, kaidah dari peraturan perundang-undangan, maupun putusan pengadilan (Marzuki, 2014: 35). Dalam penelitian ini dilakukan tiga jenis pendekatan, yaitu pendekatan konseptual (conceptual approach), pendekatan perundang-undangan (statue approach). dan pendekatan kasus (case approach).

Pendekatan kasus dalam tulisan ini memuat dua putusan untuk dianalisis yaitu Putusan Mahkamah Konstitusi Nomor 52/PUU-X/2012 dan Nomor 14/PUU-XI/2013. Kedua putusan tersebut diperoleh melalui laman www. mahkamahkonstitusi.go.id dan dijadikan sebagai sumber hukum primer, yang didukung dengan sumber hukum sekunder berupa jurnal, buku, dan artikel ilmiah serta sumber hukum tersier berupa kamus. Adapun sifat penelitian yang dipergunakan dalam tulisan ini adalah analisis preskriptif, yang bertujuan untuk menghasilkan argumentasi, teori atau konsep baru atas hasil penelitian mengenai threshold yang telah dilakukan (Al-Fatih, 2016: 24-25). Dengan demikian, yang dihasilkan oleh penelitian hukum, sekalipun bukan asas hukum yang baru atau teori baru, paling tidak argumentasi baru (Marzuki, 2014: 251).

\section{HASIL DAN PEMBAHASAN}

\section{Threshold dalam Pemilu Legislatif}

Threshold dalam pemilihan umum legislatif di Indonesia pada umumnya dikenal dengan istilah parliamentary threshold. Saat pertama kali diperkenalkan, istilah awalnya adalah electoral threshold (Widodo, 2014). Undang-Undang Nomor 3 Tahun 1999 tentang Pemilu adalah produk hukum pertama yang memuat ketentuan mengenai threshold. Peraturan mengenai threshold tercantum di dalam Pasal 39 ayat (3), yaitu:

Untuk dapat mengikuti Pemilihan Umum berikutnya, Partai Politik harus memiliki sebanyak 2\% (dua per seratus) dari jumlah kursi DPR atau memiliki sekurangkurangnya 3\% (tiga per seratus) jumlah kursi DPRD I atau DPRD II yang tersebar sekurang kurangnya di $1 / 2$ (setengah) jumlah propinsi dan di $1 / 2$ (setengah) jumlah kabupaten/kotamadya seluruh Indonesia berdasarkan hasil Pemilihan Umum.

Meskipunsecaratekstualtidakmenyebutkan frasa kata threshold, namun frasa kalimat yang terdapat dalam Pasal 39 ayat (3) tersebut sudah cukup mewakili iktikad pembuat undang-undang untuk memasukkan unsur threshold dalam undang-undang tersebut. Adapun besaran angka minimal 2\% maupun 3\% merupakan indikator teknis tentang definisi threshold seperti yang telah dijelaskan sebelumnya. Terlebih lagi, batasan angka tersebut juga menjadi syarat bagi partai politik untuk dapat mengikuti pemilu di periode berikutnya. Hal ini sejalan dengan fungsi threshold yaitu untuk memberikan batasan tertentu sesuai dengan fungsi yang ingin dicapai.

Setelah Undang-Undang Nomor 3 Tahun 1999, pemerintah kembali mengatur kebijakan tentang threshold dalam Undang-Undang Nomor 12 Tahun 2003 tentang Pemilihan Umum Anggota Dewan Perwakilan Rakyat, Dewan Perwakilan Rakyat Daerah, dan Dewan Perwakilan Daerah.

Besaran threshold yang semula sebesar $2 \%$ pada pemilu tahun 1999 , dinaikkan menjadi 
sebesar 3\% pada pemilu tahun 2004 melalui Pasal 9 ayat (1) Undang-Undang Nomor 12 Tahun 2003, yaitu:

Untuk dapat mengikuti Pemilu berikutnya, Partai Politik Peserta Pemilu harus:

a. memperoleh sekurang-kurangnya 3\% (tiga persen) jumlah kursi DPR;

b. memperoleh sekurang-kurangnya 4\% (empat persen) jumlah kursi DPRD Provinsi yang tersebar sekurangkurangnya di $1 / 2$ (setengah) jumlah provinsi seluruh Indonesia; atau

c. memperoleh sekurang-kurangnya $4 \%$ (empat persen) jumlah kursi DPRD Kabupaten/Kota yang tersebar di $1 / 2$ (setengah) jumlah kabupaten/kota seluruh Indonesia.

Meskipun terdapat kenaikan satu persen besaran angka threshold, namun pola yang dibentuk oleh pemerintah dalam merumuskan kebijakan tentang threshold masih tetap sama, antara yang ada dalam Undang-Undang Nomor 3 Tahun 1999 maupun dalam Undang-Undang Nomor 12 Tahun 2003 tentang Pemilihan Umum Anggota Dewan Perwakilan Rakyat, Dewan Perwakilan Rakyat Daerah dan Dewan Perwakilan Daerah.

Beberapa persamaan rumusan kebijakan mengenai threshold dalam kedua undang-undang tersebut meliputi: a) belum adanya definisi threshold secara tekstual dalam ketentuan umum; b) besaran threshold dinyatakan dalam angka yang perhitungannya tidak dijelaskan secara jelas, darimana angka 2\%, 3\% atau 4\% diperoleh; c) threshold diatur secara bertahap, di mana besaran angka threshold yang diterapkan untuk menghitung jumlah kursi partai politik di Dewan Perwakilan Rakyat dan Dewan Perwakilan Rakyat Daerah tidaklah sama; dan d) threshold digunakan sebagai batasan atau syarat minimum suara yang diperoleh partai politik agar dapat mengikuti pemilu di periode berikutnya.
Pada periode pemilu tahun 2009, terdapat perubahan penggunaan istilah dari electoral threshold menjadi parliamentary threshold. Regulasi tentang parliamentary threshold termaktub dalam Pasal 202 Undang-Undang Nomor 10 Tahun 2008 tentang Pemilihan Umum Anggota Dewan Perwakilan Rakyat, Dewan Perwakilan Rakyat Daerah, dan Dewan Perwakilan Daerah, yaitu:

Pasal 202

(1) Partai Politik Peserta Pemilu harus memenuhi ambang batas perolehan suara sekurang-kurangnya 2,5\% (dua koma lima perseratus) dari jumlah suara sah secara nasional untuk diikutkan dalam penentuan perolehan kursi DPR.

(2) Ketentuan sebagaimana dimaksud pada ayat (1) tidak berlaku dalam penentuan perolehan kursi DPRD provinsi dan DPRD kabupaten/kota.

Perubahan penggunaan istilah dari electoral threshold menjadi parliamentary threshold juga sekaligus merubah definisi atau pengertian secara eksplisit dari penggunaan istilah tersebut. Jika sebelumnya electoral threshold dimaknai sebagai batasan suara minimum partai agar dapat mengikuti pemilu di periode berikutnya, maka istilah parliamentary threshold dimaknai sebagai batasan suara partai politik untuk dapat mengikuti konversi perhitungan suara menjadi kursi di tingkat Dewan Perwakilan Rakyat.

Partai politik yang suaranya tidak memenuhi ambang batas atau parliamentary threshold, tidak akan diikutkan dalam perhitungan suara Dewan Perwakilan Rakyat. Regulasi mengenai parliamentary threshold juga hanya berlaku dalam penentuan perolehan kursi Dewan Perwakilan Rakyat saja, sedangkan untuk penentuan perolehan kursi Dewan Perwakilan Rakyat Daerah Provinsi dan Kabupaten/Kota 
masih menggunakan cara yang lama, yaitu melalui Bilangan Pembagi Pemilih (BPP).

Melalui Pasal 202 Undang-Undang Nomor 10 Tahun 2008 tentang Pemilihan Umum Anggota Dewan Perwakilan Rakyat, Dewan Perwakilan Rakyat Daerah, dan Dewan Perwakilan Daerah, pemerintah memperkenalkan regulasi mengenai parliamentary threshold yang mulai berlaku dalam pemilu tahun 2009. Namun seperti sebelumnya, definisi mengenai parliamentary threshold atau ambang batas belum dijelaskan di dalam bab ketentuan umum. Tidak ada penjelasan secara tekstual mengenai apa itu arti dari parliamentary threshold serta bagaimana perhitungan matematisnya untuk dapat memperoleh angka 2,5\% yang diklaim sebagai angka parliamentary threshold. Keputusan untuk memilih menggunakan parliamentary threshold sebagai pengganti electoral threshold yang telah berlaku sebelumnya adalah sebagai ikhtiar untuk mewujudkan sistem kepartaian sederhana.

\section{Pemberlakuan parliamentary threshold} menurut Mahkamah Konstitusi bersifat konstitusional, sebagaimana merujuk pertimbangan hukum dalam Putusan Nomor 3/ PUU-VII/2009 dan Nomor 52/PUU-X/2012. Mahkamah Konstitusi berpendapat bahwa penerapan parliamentary threshold tidak bersifat diskriminatif, karena kebijakan tersebut berlaku bagi seluruh partai politik peserta pemilu. Jika ada yang tidak lolos parliamentary threshold, maka hal itu adalah wajar dalam sebuah pertandingan, ada yang kalah dan ada yang menang. Sehingga, keberlakuan parliamentary threshold dalam sistem hukum pemilu di Indonesia adalah bersifat konstitusional (Al-Fatih, 2016: 51). Berikut pendapat Mahkamah Konstitusi mengenai konstitusionalisme pemberlakuan parliamentary threshold, yaitu: a. Bahwa semenjak pemilu tahun 1999 dan dilanjutkan dengan pemilu tahun 2004, pembentuk Undang-Undang melalui Undang-Undang Nomor 3 Tahun 1999 tentang Pemilihan Umum (selanjutnya disebut UU 3/1999) dan Undang-Undang Nomor 12 Tahun 2003 tentang Pemilihan Umum Anggota Dewan Perwakilan Rakyat, Dewan Perwakilan Daerah, dan Dewan Perwakilan Rakyat Daerah (selanjutnya disebut UU 12/2003) telah menerapkan kebijakan ambang batas persentase perolehan kursi atau suara bagi parpol peserta pemilu agar dapat mengikuti pemilu berikutnya yang di Indonesia lazim dikenal dengan istilah "Electoral Threshold" (disingkat ET). Melalui kebijakan ET tersebut diharapkan akan mampu menciptakan sistem kepartaian sederhana sebagaimana dikehendaki oleh Undang-Undang Nomor 2 Tahun 1999 yang kemudian diganti dengan UndangUndang Nomor 31 Tahun 2002 tentang Partai Politik. Hasil dari kebijakan tersebut, pada pemilu tahun 1999 hanya enam parpol yang memenuhi ET dan pada pemilu tahun 2004 hanya tujuh parpol yang memenuhi ET, sedangkan bagi parpol-parpol yang tidak memenuhi ET untuk dapat mengikuti pemilu berikutnya harus bergabung dengan parpol lainnya yang memenuhi ET atau tidak memenuhi ET agar memenuhi ET sesuai dengan ketentuan yang diatur dalam UU 12/2003. Meskipun jumlah parpol tetap banyak akibat berdirinya parpol-parpol baru atau parpol lama yang bermetamorfosis menjadi parpol baru, namun akibat kebijakan ET dalam UU 3/1999 jumlah parpol peserta pemilu tahun 2004 menurun 50\% dari 48 parpol pada pemilu 1999 menjadi 24 parpol pada pemilu tahun 2004, sedangkan jumlah parpol yang mendapatkan kursi di DPR pada pemilu tahun 1999 adalah 16 parpol dan pada pemilu tahun 2004 berjumlah 21 parpol;

Poin a tersebut memberikan gambaran mengenai sejarah pemberlakuan parliamentary threshold yang diawali dengan kebijakan mengenai electoral threshold dalam pemilu tahun 1999. Upaya ini dilakukan untuk membatasi 
jumlah partai politik peserta pemilu. Sebab pasca reformasi bergulir, keinginan rakyat untuk berserikat dan menyatakan pendapat sangat tinggi. Terbukti dengan banyaknya jumlah partai politik peserta pemilu tahun 1999, yakni sebesar 48 partai politik. Untuk mengurangi banyaknya jumlah partai politik peserta pemilu, pemerintah membuat kebijakan baru yang bernama electoral threshold. Electoral threshold memberikan konsekuensi logis bagi partai politik yang tidak lolos ambang batas minimum dalam pemilu tahun 1999, untuk tidak bisa mengikuti kontestasi pemilu di periode berikutnya. Kebijakan electoral threshold tersebut terbukti cukup efektif mengurangi jumlah partai politik peserta pemilu tahun 2004 hanya sejumlah 24 partai politik.

b. Terhadap kebijakan ET tersebut, Mahkamah pernah memutus permohonan pengujian kebijakan ET yang tercantum dalam Pasal 9 ayat (1) UU 12/2003 yang diajukan oleh 13 parpol peserta pemilu tahun 2004 yang tidak memenuhi ET (sebagian parpol tersebut juga mengajukan permohonan dalam Perkara Nomor 3/PUU-VII/2009) dengan argumentasi yang serupa dan mengajukan ahli yang justru mengusulkan agar ET diganti PT. Putusan Mahkamah menyatakan, permohonan ditolak dengan pertimbangan, antara lain, bahwa kebijakan ET tidak diskriminatif karena berlaku untuk semua parpol, merupakan kebijakan pembentuk Undang-Undang (legal policy) yang diamanatkan oleh Pasal 22E ayat (6) UUD NRI 1945 yang sifatnya sangat terbuka, yaitu: "Ketentuan lebih lanjut tentang pemilihan umum diatur dengan undang-undang", sehingga menurut MK, baik kebijakan ET maupun PT sama konstitusionalitasnya (vide Putusan Nomor 16/PUU-V/2007 bertanggal 23 Oktober 2007);

Dalam poin $b$ disebutkan bahwa ada dua poin utama yang menjadi tolok ukur Mahkamah Konstitusi dalam menilai konstitusionalisme diberlakukannya electoral threshold maupun parliamentary threshold. Pertama, penerapan kebijakan terkait electoral threshold maupun parliamentary threshold tidak bersifat diskriminatif, sebab electoral threshold dan parliamentary threshold berlaku bagi semua partai politik peserta pemilu tanpa adanya pengecualian. Kedua, electoral threshold dan parliamentary threshold merupakan kebijakan pembuat undang-undang (open legal policy). Kebijakan pembuat undang-undang (open legal policy) tidak bisa dimaknai sebagai sebuah kesepakatan politik, kertas kosong ataupun hal yang abstrak, melainkan harus dimaknai sebagai sebuah hal memiliki dasar, motif, tujuan dan kebutuhan konstitusional untuk menentukan pilihan-pilihan itu (Ajie, 2016: 115). Dengan mendalilkan frasa "kebijakan pembuat undang-undang (open legal policy)", Mahkamah Konstitusi berikhtiar agar besaran electoral threshold dan parliamentary threshold serta penerapannya merupakan wewenang dari pembuat undang-undang. Hal ini berarti, menjadi sebuah kebebasan bagi pembentuk undang-undang untuk mengambil kebijakan hukum (Wibowo, 2015: 211).

c. Bahwa kebijakan ET yang dianut dalam UU 3/1999 dan UU 12/2003 kemudian oleh UU 10/2008 diganti dengan kebijakan baru yang terkenal dengan istilah "Parliamentary Threshold" (disingkat PT) yang tercantum dalam Pasal 202 ayat (1) UU 10/2008 yang berbunyi: "Partai politik peserta pemilu harus memenuhi ambang batas perolehan suara sekurang-kurangnya $2,5 \%$ (dua koma lima perseratus) dari jumlah suara sah secara nasional untuk diikutkan dalam penentuan perolehan kursi DPR." Melalui kebijakan PT ini, tampaknya pembentuk Undang-Undang (DPR dan Pemerintah) bermaksud menciptakan sistem kepartaian sederhana melalui pengurangan jumlah parpol yang dapat menempatkan wakilnya di DPR, berubah dari cara sebelumnya dengan kebijakan ET yang bermaksud mengurangi jumlah peserta pemilu; ... 
... Ketentuan Pasal 22E UUD NRI 1945 tersebut menunjukkan bahwa yang menjadi rambu-rambu Konstitusi mengenai pemilu adalah: a) pemilu dilakukan secara periodik setiap lima tahun sekali; b) dianutnya asas pemilu yang bersifat langsung, umum, bebas, rahasia, jujur, dan adil; c) tujuan pemilu untuk memilih anggota DPR, DPD, DPRD, Presiden dan Wakil Presiden; d) peserta pemilu untuk memilih anggota DPR dan DPRD adalah partai politik, sedangkan peserta pemilu untuk memilih anggota DPD adalah perseorangan; dan e) penyelenggara pemilu adalah suatu komisi pemilihan umum yang bersifat nasional, tetap, dan mandiri. Dengan demikian, ketentuan selebihnya yang berkaitan dengan pemilu, misalnya tentang sistem pemilu, daerah pemilihan, syarat-syarat untuk ikut pemilu, hak pilih, dan sebagainya, oleh UUD NRI 1945 didelegasikan kepada pembentuk Undang-Undang untuk mengaturnya dalam Undang-Undang secara bebas sebagai kebijakan hukum (legal policy) pembentuk Undang-Undang, sudah barang tentu sepanjang tidak menegasikan prinsipprinsip yang terkandung dalam UUD NRI 1945, seperti prinsip kedaulatan rakyat, prinsip persamaan, prinsip keadilan, dan prinsip non diskriminasi; ..."

Berdasarkan pertimbangan Mahkamah Konstitusi di atas dapat diketahui bahwa, pemberlakuan threshold dalam rezim pemilu dimaksudkan untuk membatasi keikutsertaan partai politik dalam pemilihan umum. Hal ini dikarenakan sejak pemilu tahun 1999, jumlah partai politik yang mengikuti pemilihan umum menjadi tidak terkendali dan justru dapat menciptakan persaingan tidak sehat dalam perolehan kursi. Pemberlakuan threshold ini terbukti berhasil menyederhanakan partai politik peserta pemilu dari 48 parpol di tahun 1999 menjadi 24 parpol di tahun 2004, 16 parpol di tahun 2009 dan 10 parpol di tahun 2014. Hal ini sesuai dengan tujuan pemerintah, yaitu untuk menciptakan sistem multipartai sederhana sesuai dengan tipologi partai politik, guna menghasilkan pemerintahan yang lebih efektif dan efisien (Fadjar, 2012: 20).

Diberlakukannya threshold merupakan cara agar partai politik dapat bersaing secara sehat dalam mendulang perolehan suara dalam pemilihan umum. Selain itu, threshold mengajarkan kepada partai politik untuk tidak sekadar mengejar perolehan suara di lembaga perwakilan, tetapi juga adanya keharusan untuk melakukan kaderisasi agar tidak tereliminasi pada pemilu periode selanjutnya. Sedangkan ditinjau dari tujuannya, pemberlakuan parliamentary threshold tidaklah bersifat diskriminatif, karena semua partai politik yang besar maupun yang baru berdiri secara adil dikenai aturan threshold ini.

Bagi partai kecil yang baru terbentuk, pemberlakuan threshold ini dirasa sangat memberatkan dan dianggap sebagai bentuk diskriminasi oleh pembentuk undang-undang karena mereka harus mampu bersaing menjaga perolehan suara pemilih melewati threshold untuk tetap bertahan di pemilu periode selanjutnya. Termasuk juga harus terbuangnya suara pemilih yang partainya gagal melewati ambang minimum parliamentary threshold (Sihombing, 2009: 34). Akan tetapi dalam sejarahnya, tidak sedikit partai politik baru yang dapat melewati threshold ini seperti yang pernah dibuktikan oleh Partai Amanat Nasional dan Partai Keadilan Sejahtera di tahun 1999, Partai Demokrat di tahun 2004, Partai Gerakan Indonesia Raya dan Partai Hati Nurani Rakyat di tahun 2009 dan Partai Nasdem di tahun 2014.

\section{Parliamentary threshold dalam} penyelenggaraan pemilu di tahun 2014 diatur dalam Undang-Undang Nomor 8 Tahun 2012 tentang Pemilihan Umum Anggota Dewan Perwakilan Rakyat, Dewan Perwakilan Rakyat 
Daerah, dan Dewan Perwakilan Daerah. Beberapa

Pasal yang secara tersurat menjelaskan tentang parliamentary threshold terdapat dalam Pasal 8, 17, 208, dan 209 Undang-Undang Nomor 8 Tahun 2012, yaitu:

Pasal 8

(1) Partai politik peserta pemilu pada pemilu terakhir yang memenuhi ambang batas perolehan suara dari jumlah suara sah secara nasional ditetapkan sebagai partai politik peserta pemilu pada pemilu berikutnya.

(2) Partai politik yang tidak memenuhi ambang batas perolehan suara pada pemilu sebelumnya atau partai politik baru dapat menjadi peserta pemilu setelah memenuhi persyaratan ...

Pasal 17

(1) Partai politik sebagaimana dimaksud dalam Pasal 8 ayat (1) ditetapkan sebagai peserta pemilu dengan melampirkan dokumen persyaratan sebagaimana dimaksud dalam Pasal 15 huruf a, huruf $b$, huruf $c$, huruf $\mathrm{d}$, huruf e, huruf g, dan huruf h serta dilengkapi dengan surat keterangan memenuhi ambang batas perolehan suara DPR dari jumlah suara sah secara nasional pada pemilu sebelumnya dan perolehan kursi di DPR, DPRD provinsi, dan DPRD kabupaten/kota dari KPU.

Pasal 208

Partai politik peserta pemilu harus memenuhi ambang batas perolehan suara sekurang-kurangnya $3,5 \%$ (tiga koma lima persen) dari jumlah suara sah secara nasional untuk diikutkan dalam penentuan perolehan kursi anggota DPR, DPRD provinsi, dan DPRD kabupaten/kota.

Pasal 209

(1) Partai politik peserta pemilu yang tidak memenuhi ambang batas perolehan suara sebagaimana dimaksud dalam Pasal 208, tidak disertakan pada penghitungan perolehan kursi DPR, DPRD provinsi, dan DPRD kabupaten/kota di setiap daerah pemilihan.
(2) Suara untuk penghitungan perolehan kursi DPR, DPRD provinsi, dan DPRD kabupaten/kota di suatu daerah pemilihan ialah jumlah suara sah seluruh partai politik peserta pemilu dikurangi jumlah suara sah partai politik peserta pemilu yang tidak memenuhi ambang batas perolehan suara sebagaimana dimaksud dalam Pasal 208.

Meskipun threshold secara tersirat telah diatur sejak rezim pemilu tahun 1999, tetapi definisi secara tekstual tentang parliamentary threshold masih belum dapat ditemukan dalam Undang-Undang Nomor 8 Tahun 2012 tersebut. Seperti dalam beberapa undang-undang sebelumnya, dalam undang-undang tersebut hanya menyebutkan secara eksplisit tentang makna parliamentary threshold. Perubahan yang cukup signifikan adalah terkait besaran angka parliamentary threshold dari 2,5\% pada pemilu legislatif tahun 2009 menjadi 3,5\% pada pemilu legislatif tahun 2014. Selain itu, terdapat juga beberapa pasal yang dianggap rawan menimbulkan kontroversi karena dianggap bias dan multitafsir seperti dalam Pasal 208 ini yang mengamanatkan permberlakuan threshold secara nasional. Hal ini dibuktikan dengan banyak diajukannya judicial review terhadap Pasal 208 sehingga parliamentary threshold hanya berlaku untuk penentuan perolehan kursi Dewan Perwakilan Rakyat saja, dan tidak berlaku untuk Dewan Perwakilan Rakyat Daerah Provinsi maupun Dewan Perwakilan Rakyat Daerah Kabupaten/Kota, sesuai dengan Putusan Mahkamah Konstitusi Nomor 52/PUU-X/2012.

Sebagaimana disebutkan dalam amar Putusan Mahkamah Konstitusi Nomor 52/ PUU-X/2012 poin 14 dan 19 yang menyebutkan bahwa Pasal 208 Undang-Undang Nomor 8 Tahun 2012 tentang Pemilihan Umum Anggota Dewan 
Perwakilan Rakyat, Dewan Perwakilan Daerah, dan Dewan Perwakilan Rakyat Daerah sepanjang frasa "DPRD provinsi, dan DPRD kabupaten/ kota" bertentangan dengan UUD NRI 1945 dan tidak mempunyai kekuatan hukum mengikat.

Mahkamah Konstitusi dalam pertimbangan hukumnya berpendapat bahwa pemberlakuan parliamentary threshold secara nasional tidak mengakomodasi semangat persatuan dalam keberagaman, berpotensi menghalangi aspirasi politik di tingkat daerah serta bertentangan dengan kebhinekaan dan kekhasan aspirasi politik yang beragam di setiap daerah. Dengan diberlakukannya parliamentary threshold secara nasional, maka dapat mengurangi, membatasi, dan menghilangkan hak berpolitik masyarakat di daerah. Karena bisa jadi suatu partai politik tidak lolos parliamentary threshold secara nasional, namun di beberapa daerah partai politik tersebut memperoleh suara cukup signifikan atau bahkan menjadi peraih suara mayoritas. Tentunya, hal ini bertentangan dengan prinsip kedaulatan rakyat, hak politik, dan rasionalitas.

Argumen tersebut sejalan dengan amanat yang tertuang dalam Pasal 22E ayat (2) UUD NRI 1945 yang menyatakan bahwa: "Pemilihan Umum diselenggarakan untuk memilih anggota Dewan Perwakilan Rakyat, Dewan Perwakilan Daerah, Presiden dan Wakil Presiden, dan Dewan Perwakilan Rakyat Daerah." Meskipun diselenggarakan secara bersamaan dalam satu waktu, namun pemilihan umum legislatif pada dasarnya adalah untuk memilih objek dan sasaran yang berbeda. Objek tersebut terbagi menjadi Dewan Perwakilan Rakyat, Dewan Perwakilan Daerah, Dewan Perwakilan Rakyat Daerah Provinsi, dan Dewan Perwakilan Rakyat Daerah Kabupaten/Kota. Perbedaan ini seharusnya dapat dijadikan sebagai landasan untuk memberlakukan kebijakan yang berbeda pula dalam penentuan parliamentary threshold. Alhasil, tidak dibenarkan memberlakukan parliamentary threshold secara nasional karena secara objek sudah jelas berbeda.

Dengan diberlakukannya parliamentary threshold secara nasional, maka akan mereduksi pemberian hak suara ke calon Dewan Perwakilan Rakyat Daerah. Berdasarkan dalil yang terdapat dalam Putusan Mahkamah Konstitusi Nomor 52/ PUU-X/2012, disebutkan bahwa sebagai salah satu wujud pelaksanaan kedaulatan rakyat, suara yang ditujukan ke dalam kotak suara tertentu, tidak boleh menegaskan dan mereduksi makna pemberian suara ke kotak suara yang lain. Hal ini berarti masing-masing kotak sebagai representasi hak suara sebagai hak asasi untuk memilih, memiliki nilai keterwakilan masing-masing, sehingga tidak mungkin karena tidak mencapai pada ambang batas tertentu pada kota tertentu menghilangkan representasi pada kotak yang lain. Pemberlakuan threshold secara nasional juga dikhawatirkan dapat menghilangkan suara pemilih sebagaimana yang pernah terjadi dalam pemilu legislatif tahun 2009.

Padahal, penyelenggaraan pemilu sangat terkait dengan persoalan hak asasi manusia. Pemilu sebagai mekanisme demokrasi modern adalah wujud dari prinsip kedaulatan rakyat yang menempatkan manusia dalam derajat yang sama. Pemilu adalah wujud nyata pengakuan hak asasi manusia dalam kehidupan bernegara (Gaffar, 2013a: 9). Oleh karena itu, pemilu yang demokratis hanya mungkin diselenggarakan jika ada perlindungan hak asasi manusia. Pemilu membutuhkan jaminan hak-hak politik antara lain kebebasan berkeyakinan, kebebasan mengeluarkan pendapat, kebebasan berserikat dan berkumpul, hak persamaan di depan hukum 
dan pemerintahan serta hak pilih dan dipilih. Sedangkan hak asasi manusia yang terkait dengan penyelenggaraan pemilu termasuk ke dalam kategori hak politik. Artinya, hak ini melekat dalam status sebagai warga negara. Oleh karena itu, kewajiban negara lebih kepada melindungi (obligation to protect) agar hak itu dapat dinikmati dan dijalankan. Peran negara dalam hal ini lebih bersifat pasif, artinya hanya menjaga agar tidak ada pihak lain yang melanggar hak tersebut (Gaffar, 2013b: 9).

Dari uraian tersebut, dapat disimpulkan beberapa alasan yang melandasi sifat inkonstitusional pemberlakuan parliamentary threshold secara nasional di antaranya adalah:

1. Kedudukan Dewan Perwakilan Rakyat berbeda dengan Dewan Perwakilan Rakyat Daerah. Dewan Perwakilan Rakyat bersifat nasional dan menjalankan fungsi penyeimbang kekuasaan presiden dalam sistem checks and balances. Sedangkan kekuasaan Dewan Perwakilan Rakyat Daerah termasuk bagian dari pemerintahan daerah;

2. Pemberlakuan parliamentary threshold secara nasional tidak mengakomodasi semangat persatuan dalam keberagaman, bertentangan dengan kebhinekaan dan kekhasan aspirasi politik yang beragam di setiap daerah;

3. Parliamentary threshold yang diberlakukan secara nasional berpotensi menghalangi aspirasi politik di tingkat daerah (Jati, 2013: 158). Bahkan, bisa menciptakan suatu kondisi di mana anggota Dewan Perwakilan Rakyat Daerah terpilih tidak merepresentasikan suara pemilih di daerahnya karena parpol pengusung tidak lolos parliamentary threshold secara nasional;

4. Pemberlakuan parliamentary threshold secara nasional bertentangan dengan kedaulatan rakyat, hak politik, dan rasionalitas, sehingga bertentangan pula dengan tujuan pemilu itu sendiri yaitu untuk memilih wakil rakyat dari tingkat pusat hingga daerah. Artinya, pemilihan wakil rakyat dari tingkat pusat hingga daerah seharusnya dilakukan berdasarkan prinsip kedaulatan rakyat dan pemberian hak berpolitik yang seluas-luasnya.

Meskipun pemilihan umum anggota Dewan Perwakilan Rakyat, Dewan Perwakilan Rakyat Daerah Provinsi, dan Dewan Perwakilan Rakyat Daerah Kabupaten/Kota diselenggarakan dalam waktu yang bersamaan, namun bukan berarti dasar pemberlakuan parliamentary threshold dalam pemilu juga harus disamakan. Antara Dewan Perwakilan Rakyat dan Dewan Perwakilan Rakyat Daerah memiliki tugas, wewenang serta tanggung jawab yang berbeda. Oleh karenanya, sudah seyogianya dasar pemberlakuan parliamentary threshold untuk pemilihan anggota Dewan Perwakilan Rakyat dan Dewan Perwakilan Rakyat Daerah dibedakan pula. Dasar pertimbangan hukum yang menjadi pandangan Mahkamah Konstitusi sebagaimana telah diuraikan di atas, seharusnya menjadi alasan yang bisa diterima secara logis bagi seluruh masyarakat Indonesia.

Penerapan parliamentary threshold harus tetap berlaku pada masing-masing wilayah pemilihan. Jika parliamentary threshold hendak diterapkan pada pemilihan umum anggota Dewan Perwakilan Rakyat Daerah Provinsi, maka parliamentary threshold tersebut hanya berlaku untuk wilayah pemilihan tingkat provinsi saja. 
Sama halnya jika parliamentary threshold hendak diterapkan pada pemilihan umum anggota Dewan Perwakilan Rakyat Daerah Kabupaten/Kota, maka parliamentary threshold tersebut hanya berlaku untuk wilayah pemilihan tingkat kabupaten/kota. Sehingga, apabila pembentuk undang-undang tetap berkonsisten dan berkeinginan menerapkan parliamentary threshold, maka seharusnya dalam undang-undang pemilu ke depannya harus diatur pembagian dan besaran threshold untuk tiga pemilihan yang berbeda, yaitu threshold untuk pemilihan Dewan Perwakilan Rakyat dan Dewan Perwakilan Daerah; threshold untuk pemilihan Dewan Perwakilan Rakyat Daerah Provinsi dan threshold untuk pemilihan Dewan Perwakilan Rakyat Daerah Kabupaten/Kota.

Sementara itu, dalam pemilu serentak tahun 2019, pemerintah melalui Undang-Undang Nomor 7 Tahun 2017 tentang Pemilihan Umum, menetapkan parliamentary threshold sebesar 4\% sebagaimana diamanatkan dalam Pasal 414 ayat (1). Polemik mengenai keberlakuan parliamentary threshold secara nasional memang telah diakhiri oleh Putusan Mahkamah Konstitusi Nomor 52/ PUU-X/2012, namun bukan tidak mungkin dengan disahkannya Undang-Undang Nomor 7 Tahun 2017 akan membuka permasalahan yang lain.

Hal ini nampak dari definisi parliamentary threshold itu sendiri yang seyogianya secara tekstual dijelaskan dalam Undang-Undang Nomor 7 Tahun 2017, namun ternyata tidak ada. Hal ini penting untuk mengurangi perbedaan penafsiran terkait parliamentary threshold. Selain itu, naiknya angka parliamentary threshold menjadi sebesar 4\% juga dikhawatirkan dapat merampas hak berpolitik warga negara, sehingga UndangUndang Nomor 7 Tahun 2017 berpeluang besar untuk digugat ke Mahkamah Konstitusi.
Berdasarkan penjelasan di atas, terdapat beberapa akibat hukum yang ditimbulkan dari regulasi tentang parliamentary threshold dalam pemilu legislatif pasca Putusan Mahkamah Konstitusi Nomor 52/PUU-X/2012 dan Nomor 14/PUU-XI/2013, di antaranya:

a. Ketidakselarasan penafsiran parliamentary threshold oleh pandangan Mahkamah Konstitusi dan pembentuk undang-undang dapat membuka peluang terjadinya konflik kepentingan akibat penerapan parliamentary threshold tersebut. Meskipun pemerintah telah berhasil melakukan kodifikasi Undang-Undang Pemilu, namun hal tersebut belum cukup mampu untuk menjawab permasalahan yang pernah terjadi karena ternyata penafsiran parliamentary threshold di dalam penerapannya tidak sejalan dengan semangat dan pandangan Mahkamah Konstitusi.

b. Berkaitan dengan parliamentary threshold, Mahkamah Konstitusi memberikan amanah berupa ketentuan mengenai open legal policy kepada pemerintah selaku pembuat undangundang, namun pembuat undang-undang justru tidak menjalankan amanah tersebut dengan baik. Keadaan ini menguatkan Mahkamah Konstitusi sebagai negative legislature, bahwa Mahkamah Konstitusi bukanlah pembuat norma hukum.

c. Pemberlakuan parliamentary threshold tidak berlaku secara nasional, sehingga mengakomodasi hak-hak partai politik dan konstituen di daerah.

d. Parliamentary threshold merupakan regulasi yang wajar dan tidak diskriminatif, sebagai upaya untuk menyederhanakan 
jumlah partai politik dalam sistem multipartai sederhana. Terkait adanya partai politik yang tidak lolos ke parlemen akibat adanya regulasi mengenai parliamentary threshold tersebut, hal itu merupakan sebuah kewajaran dalam setiap kontestasi.

\section{Threshold dalam Pemilihan Presiden}

Threshold juga dikenal dalam pemilihan presiden di Indonesia yang biasa disebut dengan istilah presidential threshold. Istilah tersebut tidak mengalami perubahan sejak pertama kali diperkenalkan dalam pilpres tahun 2004. Melalui Undang-Undang Nomor 23 Tahun 2003 tentang Pemilihan Umum Presiden dan Wakil Presiden, pemerintah menerapkan aturan baru untuk pilpres tahun 2004. Aturan baru tersebut lazim dikenal dengan istilah presidential threshold atau ambang batas suara minimum partai politik agar dapat mengirimkan calonnya dalam ajang pilpres. Regulasi mengenai presidential threshold dapat ditemukan dalam Pasal 5 ayat (4) UndangUndang Nomor 23 Tahun 2003 tentang Pemilihan Umum Presiden dan Wakil Presiden, yaitu:

(4) Pasangan Calon sebagaimana dimaksud pada ayat (1) hanya dapat diusulkan oleh partai politik atau gabungan partai politik yang memperoleh sekurang-kurangnya 15\% (lima belas persen) dari jumlah kursi DPR atau 20\% (dua puluh persen) dari perolehan suara sah secara nasional dalam pemilu anggota DPR.

Dalam pasal tersebut dijelaskan mengenai presidential threshold sebesar 15\% dari jumlah kursi Dewan Perwakilan Rakyat, atau 20\% dari perolehan suara sah secara nasional dalam pemilu anggota Dewan Perwakilan Rakyat. Besaran presidential threshold merupakan syarat bagi partai politik atau gabungan partai politik (dikenal juga dengan istilah koalisi) agar dapat mengajukan calon presiden dan wakil presiden dalam ajang pilpres. Dengan dikeluarkannya regulasi mengenai presidential threshold tersebut, maka sejak pemilu tahun 2004, Indonesia mengenal dua jenis threshold, yaitu electoral threshold dan presidential threshold.

Pemberlakuan presidential threshold ini merupakan konsekuensi dari diadopsinya pemilihan presiden dan wakil presiden secara langsung oleh rakyat. Namun sebenarnya penerapan presidential threshold juga berpotensi hilangnya kesempatan dan hak warga negara melalui partai politik yang tidak memenuhi besaran angka yang telah ditentukan untuk mengajukan calonnya. Oleh sebab itu, perlu diperhatikan juga prinsip demokrasi dalam penentuan ambang batas presidential threshold agar tidak merugikan kelompok masyarakat tertentu terutama masyarakat minoritas. Sehingga, pemberlakuan presidential threshold harus mencerminkan dan memperhatikan keragaman masyarakat yang tercermin dalam aspirasi politik (Wijaya, 2014: 564).

Selain itu, penentuan presidential threshold perlu dilakukan secara proporsional serta memperhatikan keseimbangan antara politik hukum penyederhanaan partai dan perlindungan terhadap keragaman politik. Oleh karenanya, penentuan presidential threshold tidak boleh berdasarkan pertimbangan keuntungan dan kerugian yang didapat oleh partai politik.

Pengaturan mengenai presidential threshold juga mengalami perubahan pada pilpres tahun 2009, sebagaimana diatur dalam Pasal 9 Undang-Undang Nomor 42 Tahun 2008 tentang Pemilihan Umum Presiden dan Wakil Presiden, yaitu: 
Pasal 9

Pasangan calon diusulkan oleh partai politik atau gabungan partai politik peserta pemilu yang memenuhi persyaratan perolehan kursi paling sedikit 20\% (dua puluh persen) dari jumlah kursi Dewan Perwakilan Rakyat atau memperoleh $25 \%$ (dua puluh lima persen) dari suara sah nasional dalam pemilu anggota Dewan Perwakilan Rakyat, sebelum pelaksanaan pemilu Presiden dan Wakil Presiden.

Ketentuan mengenai presidential threshold tersebut mengalami perubahan pada besaran angka, dari $15 \%$ menjadi $20 \%$. Sedangkan untuk pilpres tahun 2014, regulasi terkait presidential threshold tidak berubah dan tetap berpedoman pada ketentuan dalam Undang-Undang Nomor 42 Tahun 2008 tentang Pemilihan Umum Presiden dan Wakil Presiden. Perubahan ketentuan terkait presidential threshold baru akan terjadi saat pemilu serentak di tahun 2019.

Pemilu serentak merupakan amanah Putusan Mahkamah Konstitusi Nomor 14/PUUXI/2013. Melalui putusan tersebut, Mahkamah Konstitusi berpendapat bahwa kebijakan terkait threshold bersifat open legal policy atau dikembalikan kepada pembuat undang-undang. Dinamika penerapan presidential threshold dalam pemilu serentak di tahun 2019 akhirnya bermuara pada keputusan bahwa besaran angka presidential threshold sebagai syarat bagi parpol untuk bisa mengusung capres dan cawapres adalah merujuk pada hasil pemilu pada periode sebelumnya.

Sebagaimana telah disebutkan sebelumnya, dalam pemilu serentak tahun 2019, pemerintah melalui Undang-Undang Nomor 7 Tahun 2017 tentang Pemilihan Umum, menetapkan angka presidential threshold sebesar 20\% (dua puluh persen) dari jumlah kursi Dewan Perwakilan
Rakyat atau memperoleh 25\% (dua puluh lima persen) dari suara sah nasional dalam pemilu anggota Dewan Perwakilan Rakyat. Meskipun besaran angka presidential threshold dalam pilpres tahun 2019 tidak mengalami perubahan, namun adanya ketentuan bahwa angka presidential threshold sebagai syarat bagi parpol untuk bisa mengusung capres dan cawapres adalah merujuk pada hasil pemilu pada periode sebelumnya, membuat banyak masyarakat kecewa. Oleh karenanya, disahkannya UndangUndang Nomor 7 Tahun 2017 tentang Pemilihan Umum tidak serta merta memberikan solusi, namun justru membuka peluang lahirnya konflik kepentingan di tengah masyarakat. Setidaknya, sudah ada judicial review terhadap undangundang tersebut yang dilakukan oleh Yusril Ihza Mahendra selaku perwakilan dari Partai Bulan Bintang dan Rhoma Irama selaku perwakilan dari Partai Idaman (Mahendra, 2015).

Menurut hemat penulis, seharusnya presidential threshold tidak perlu diterapkan pada rezim pemilu tahun 2019 nanti. Sebagaimana disampaikan pula oleh Muzakir, penerapan presidential threshold dalam pemilu serentak dianggap tidak relevan (Muzakir, 2016).

Hal ini disebabkan karena pelaksanaan pemilihan presiden dan wakil presiden yang secara serentak dengan pemilihan anggota legislatif. Hasil pemilu legislatif biasanya menjadi dasar bagi parpol untuk berkoalisi dalam pengusungan calon presiden dan calon wakil presiden maupun koalisi dalam pemerintahan apabila pasangan yang diusung memenangkan pemilu presiden dan wakil presiden.

Ini berarti bahwa, presidential threshold pada pemilu serentak tahun 2019 seharusnya tidak ditujukan untuk syarat pencalonan presiden 
dan wakil presiden, melainkan lebih kepada syarat koalisi dalam pemerintahan. Jika pada pemilu tahun 2019 presidential threshold tetap dipaksakan untuk diberlakukan, maka seperti mengutip pendapat Habibullah, seyogianya dilakukan dua tahap pemilu, yaitu pra pemilu dan pemilu itu sendiri. Pra pemilu bertujuan untuk menyaring dukungan agar besaran presidential threshold yang diterapkan tidak siasia (Habibullah, 2015: 94).

Berdasarkan penjelasan di atas, terdapat beberapa akibat hukum yang ditimbulkan dari regulasi tentang presidential threshold dalam pemilu presiden pasca Putusan Mahkamah Konstitusi Nomor 14/PUU-XI/2013, di antaranya: Pertama, adanya koalisi partai politik dalam hal mengusung calon presiden dan calon wakil presiden dapat mengakibatkan terjadinya tukarmenukar kepentingan (pendapat Mahkamah Konstitusi dalam Putusan Nomor 14/PUU$\mathrm{XI} / 2013) ;$ Kedua, apabila parpol pengusung calon presiden dan calon wakil presiden terpilih nantinya tidak menguasai parlemen, maka kebijakan presiden dapat terhambat karena tidak didukung oleh mayoritas anggota di parlemen (pendapat Mahkamah Konstitusi dalam Putusan Nomor 14/PUU-XI/2013); Ketiga, parpol baru yang baru saja berkompetisi dalam pemilu serentak tahun 2019 tidak dapat mengusung calon presiden dan wakil presiden karena tidak memiliki parliementary threshold, namun apabila nantinya parpol baru tersebut memiliki perolehan kursi yang besar maka berpotensi dapat membentuk poros baru di luar poros koalisi dan oposisi; dan d) Keempat, ketidakberanian Mahkamah Konstitusi dalam menafsirkan presidential threshold beserta besarannya secara matematis, rawan dimaknai oleh pembuat undang-undang dan elite politik dengan sikap politik transaksional.

\section{KESIMPULAN}

Berdasarkan uraian di atas dapat disimpulkan bahwa Putusan Mahkamah Konstitusi Nomor 52/PUU-X/2012 dan Nomor 14/PUU-XI/2013 berkaitan dengan regulasi tentang threshold menimbulkan beberapa akibat hukum. Dalam pemilu legislatif, akibat hukum yang ditimbulkan adalah berkaitan dengan: a) Ketidakselarasan penafsiran parliamentary threshold oleh pandangan Mahkamah Konstitusi dan pembentuk undang-undang dapat membuka peluang terjadinya konflik kepentingan akibat penerapan parliamentary threshold tersebut; b) Parliamentary threshold tidak berlaku secara nasional, sehingga mengakomodasi hak-hak partai politik dan konstituen di daerah; dan c) Parliamentary threshold merupakan regulasi yang wajar dan tidak diskriminatif, sebagai upaya untuk menyederhanakan jumlah partai politik dalam sistem multipartai sederhana.

Dalam pemilu presiden, akibat hukum yang ditimbulkan adalah berkaitan dengan: a) Adanya koalisi partai politik dalam hal mengusung calon presiden dan calon wakil presiden dapat mengakibatkan terjadinya tukar-menukar kepentingan; b) Apabila parpol pengusung calon presiden dan calon wakil presiden terpilih nantinya tidak menguasai parlemen, maka kebijakan presiden dapat terhambat karena tidak didukung oleh mayoritas anggota di parlemen; c) Parpol baru yang baru saja berkompetisi dalam pemilu serentak tahun 2019 tidak dapat mengusung calon presiden dan wakil presiden karena tidak memiliki parliementary threshold, namun apabila nantinya parpol baru tersebut memiliki perolehan kursi yang besar maka berpotensi dapat membentuk poros baru dil uar poros koalisi dan oposisi; dan d) Ketidakberanian Mahkamah Konstitusi dalam menafsirkan presidential threshold beserta 
besarannya secara matematis, rawan dimaknai oleh pembuat undang-undang dan elite politik dengan sikap politik transaksional.

\section{DAFTAR PUSTAKA}

Ajie, R. (2016). Batasan pilihan kebijakan pembentuk undang-undang (Open legal policy) dalam pembentukan peraturan perundang-undangan berdasarkan tafsir Putusan Mahkamah Konstitusi. Jurnal Legislasi Indonesia, 13(2), 111-120.

Al-Fatih, S. (2015). Reformulasi parliamentary threshold yang berkeadilan dalam pemilu legislatif di Indonesia. Skripsi tidak diterbitkan. Malang: Fakultas Hukum Universitas Brawijaya.

. (2016). Eksistensi threshold dalam pemilu serentak. Tesis tidak diterbitkan. Surabaya: Fakultas Hukum Universitas Airlangga.

Appadorai. (1974). The substance of politic. New Delhi: Oxford India Paperback.

Ash-Shallabi, A.M. (2016). Parlemen di negara Islam modern: Hukum demokrasi, pemilu, \& golput. Jakarta: Pustaka Al-Kautsar.

Asprian, W. (2014). Keluarkan kronologi resmi keluarnya putusan pemilu serentak 2019. Diakses dari http://analisadaily.com/.

Asshiddiqie, J. (2006). Pengantar ilmu hukum tata negara. Jilid II. Jakarta: Mahkamah Konstitusi Republik Indonesia.

(2009). Menuju negara hukum yang demokratis. Jakarta: Gramedia. (2010). Konstitusi ekonomi. Jakarta: Kompas.
Corry, J.A. (1960). Democratic government \& polities. Toronto: University of Toronto Press.

Departemen Pendidikan Nasional (Depdiknas). (2012). Kamus Besar Bahasa Indonesia. Edisi ke-4. Jakarta: PT. Gramedia Pustaka Utama.

Erfandi. (2014). Parliamentary threshold \& HAM dalam hukum tata negara Indonesia. Malang: Setara Press.

Firdaus, S.U. (2011). Relevansi parliamentary threshold terhadap pelaksanaan pemilu yang demokratis. Jurnal Konstitusi, 8(2), 91-112.

Gaffar, J.M. (2013a). Demokrasi \& pemilu di Indonesia. Jakarta: KONpress.

(2013b, Maret). Peran putusan Mahkamah Konstitusi dalam perlindungan hak asasi manusia terkait penyelenggaraan pemilu. Jurnal Konstitusi, 10(1), 1-32.

Goodwin-Gill, G.S.(1994). Pemilujurdil, pengalaman \& standar internasional. Jakarta: Pirac \& The Asia Foundation.

Gumay, H.N. (2011). Parliamentary threshold lebih efektif menjaring parpol berkualitas. Diakses dari http://www.hukumonline.com.

Habibullah, A.W. (2015). Pemberlakuan presidentil threshold dalam pemilu serentak. Tesis tidak diterbitkan. Surabaya: Fakultas Hukum Universitas Airlangga.

Hakim, A.A. (2011). Negara hukum \& demokrasi di Indonesia. Yogyakarta: Pustaka Pelajar.

Hornby, A.S. (2003). Oxford Advanced Learner's Dictionary. $6^{\text {th }}$ Edition. Oxford: Oxford University Press.

Isra, S., et al. (2014). Pemilihan umum serentak. Jakarta: Rajawali Pers.

Jati, W.R. (2013). Menuju sistem pemilu dengan 
ambang batas parlemen yang afirmatif. Jurnal Yudisial, 6(2), 143-158.

Junaidi, V., et al. (2013). Politik hukum sistem pemilu. Jakarta: Perkumpulan Untuk Pemilu \& Demokrasi (Perludem).

Jurdi, F. (2011). Hantu "digul" parliamentary threshold. Diakses dari http://www. negarahukum.com/.

Lijphart, A. (2012). Patterns of democracy, government forms \& performance in thirty-six countries. $2^{\text {nd }}$ Edition. Yale: Yale University Press.

Mahendra, Y.I. (2015). Pemilu serentak, parliamentary threshold \& presidential threshold tak ada lagi. Diakses dari http://poskotanews.com/.

Mahfud MD, M. (1999). Hukum \& pilar-pilar demokrasi. Yogyakarta: Gama Media.

Marzuki, P.M. (2014). Penelitian hukum. Cetakan ke9. Jakarta: Kencana Media Group.

Mellaz, A. (2012). Ambang batas tanpa batas: Praktek penerapan keberlakuan 3,5\% persen ambang batas parlemen secara nasional Undang-Undang Nomor 8 Tahun 2012 tentang Pemilu. Diakses dari http://rumahpemilu.org.

Moraski, B., \& Loewenberg, G. (1999). 'The effect of legal thresholds on the revival of former communist parties in East-Central Europe.' The Journal of Politics, 61(1), 151-170.

Muzakir. (2016). Pileg \& pilpres serentak 2019, presidential threshold tidak perlu lagi. Diakses dari http://poskotanews.com/.

Raditya, I.G.N.A.S. (2013). Pengaturan ambang batas formal (Formal threshold) dalam konteks sistem pemilihan umum yang demokratis $\mathrm{di}$ Indonesia. Tesis tidak diterbitkan. Denpasar: Fakultas Hukum Universitas Udayana.
Reilly, B., \& Reynolds, A. (1998). Electoral system, sistem pemilu. Terjemahan oleh Tim IFES Indonesia. (2001). Jakarta: IFES Indonesia.

Senyuva, O. (2010). 'Parliamentary electios in Moldova April and July 2009.' Elsevier Journal, Electoral Studies, xxx, 1-6.

Sihombing, E.N.A.M. (2009). Pemberlakuan parliamentary threshold \& kaitannya dengan hak asasi manusia. Jurnal Konstitusi, 1(1), 2536 .

Sodikin. (2014). Hukum pemilu: Pemilu sebagai praktek ketatanegaraan. Bekasi: Gramata Publising.

Soedarsono. (2006). Mahkamah Konstitusi sebagai pengawal demokrasi. Jakarta: Sekjen dan Kepaniteraan Mahkamah Konstitusi RI.

Wibowo, M. (2015). Menakar konstitusionalitas sebuah kebijakan hukum terbuka dalam pengujian undang-undang. Jurnal Konstitusi, 12(2), 196-216.

Widodo, S. (2014). Analisis yuridis parliamentary threshold dalam Undang-Undang Nomor 8 Tahun 2012 tentang Pemilihan Umum Anggota $D P R, D P D \& D P R D$. Diakses dari http://www. oxpdf.com/.

Wijaya, I.D.M.P. (2014). Mengukur derajat demokrasi Undang-Undang Nomor 42 Tahun 2008 tentang Pemilihan Umum Presiden \& Wakil Presiden. Jurnal IUS, 11(6), 556-571. 